\title{
Surirella wulingensis sp. nov. and fine structure of $S$. tientsinensis Skvortzov (Bacillariophyceae) from China
}

\author{
Bing Liu ${ }^{*}$, Saúl BlanCo ${ }^{2,3}$, Luc ECTOR ${ }^{4}$, Zhu-xiang LiU ${ }^{1} \&$ Juan AI ${ }^{1}$ \\ ${ }^{1}$ College of Biology and Environmental Science, Jishou University, Jishou 416000, China; *Corresponding \\ authore-mail: jsulb@outlook.com \\ ${ }^{2}$ Departamento de Biodiversidad y Gestión Ambiental, Facultad de Ciencias Biológicas y Ambientales, \\ Universidad de León, Campus de Vegazana s/n, 24071, León, España \\ ${ }^{3}$ Laboratorio de diatomología y calidad de aguas, Instituto de Investigación de Medio Ambiente, Recursos \\ Naturales y Biodiversidad, La Serna 58, 24007, León, España \\ ${ }^{4}$ Luxembourg Institute of Science and Technology (LIST), Department of Environmental Research and \\ Innovation, 41 rue du Brill, L-4422 Belvaux, Luxembourg
}

\begin{abstract}
Two Surirella species from China are studied using light and scanning electron microscopy. Surirella wulingensis sp. nov., discovered from Li River (located in Wuling Mountains, China), bears five undulations from pole to pole throughout the whole valve diminution series and parallel valve margins, which differ from other similar taxa. Based on the observations of the fine structure, an amended description is provided for $S$. tientsinensis which possesses a unique character within the genus Surirella: rounded and rimmed outer openings of areolae. Three new morphological terms are proposed: costa-stria bundle (CSB), over-fibula costa (OFC), and mantle sinking against a fibula (MSAF), which can be used for describing some Surirella taxa more succinctly and explicitly including these taxa in this study.
\end{abstract}

Key words: corresponding relationship, diatom, fine structure, new species, rimmed opening

\section{INTRODUCTION}

Surirella Turpin is a diversified diatom genus that inhabits mostly epipelic environments in world freshwater and brackish water ecosystems. Surirella was divided by Peragallo \& Peragallo (1897-1908) into three groups: Fastuosae, Robustae and Pinnatae, although this traditional differentiation based on morphology is not supported by either formal morphological (RUCK \& KocIOLEK 2004) or molecular analyses (RUCK et al. 2016). RucK et al. (2016) proposed morphological synapomorphies for each of these groups: a synapomorphy for Fastuosae group is a communication between the raphe canal and cell interior through a funnel- or chalice-shaped structure, for Pinnatae group is the raphe canal located directly on the mantle, for the Robustae group synapomorphies are the raphe canal raised above the valve and mantle and having alar canals with fenestral openings occluded by fenestral bars. According to RUCK et al. (2016), Surirella sensu stricto is restricted to the Surirella Pinnatae plus Cymatopleura W. Smith (JAHN et al. 2017). Although Cymatopleura taxa now can be merged into the genus
Surirella sensu stricto, they are still a distinctive group with unique valve surface undulations from pole to pole.

Surirella librile (Ehrenberg) EHRENBERG (1845) was commonly regarded as a member of Cymatopleura, has been reported worldwide under the much more common name Cymatopleura solea (Brébisson) W. Smith (e.g. Mann 1987; Krammer \& Lange-Bertalot 1987; RUCK \& KocioleK 2004). RUCK \& KocioleK (2004) thoroughly examined the population of S. librile from Big Swamp Lake of Washington using scanning electron microscopy (SEM) and reviewed the previous SEM micrographs of S. librile. However, some details of the valve surface, for example, the external areola openings, the pattern of external costae alternating with striae, the relationship between the external costae and the internal fibulae, and the girdle, are still worth investigating more closely. To our knowledge, no Surirella librile population from China has been thoroughly examined using SEM. Thus, with the available information, the conspecificity of Chinese populations with S. librile cannot be confirmed yet. Another poorly studied Surirella species is S. tientsinensis Skvortzov, originally described by SkvorTzov in 1927 
from Tientsin, North China (Skvortzov 1927). Later, this taxon was reported from Russia (e.g. SKvortzov 1938; ObreZKova 2009; Kharitonov 2010); Japan (e.g. HaraguChi 1997, 2000); and China (e.g. FAN \& Hu 2004), although never examined using SEM so far.

Concerning Chinese Cymatopleura, two new species from China have been described, focusing on the twisting valves (You et al. 2017), with no further reports in the literature. To date, the diatoms of Dongting Lake have been understudied. LiU et al. (2018b) described a new interesting Entomoneis species from this habitat, not reported elsewhere to date. Another interesting diatom biodiversity hotspot is Wuling Mountains, with numerous rivers, streams and brooks. Liu and collaborators have described many new diatom species from this area in recent years (e.g. LIU et al. 2016, 2017, 2018a). The present paper examines populations of both Surirella librile and S. tientsinensis from Dongting Lake and describes a new species of Surirella found in Li River (Wuling Mountains), China. A correspondence between some valve external and internal elements are clearly illustrated for these three taxa, and an amended description is provided for S. tientsinensis.

\section{Material ANd Methods}

Dongting Lake is the second largest freshwater lake in China, is located between coordinates $28^{\circ} 30^{\prime}-30^{\circ} 20^{\prime} \mathrm{N}$ and $111^{\circ} 40^{\prime}-$ $113^{\circ} 40^{\prime} \mathrm{E}$ in the northeastern part of Hunan Province. It has four inputs from Xiang, $\mathrm{Zi}$, Yuan, and Li Rivers respectively, and three inputs from the Yangtze River's three outlets (Songzi, Hudu, and Ouchi, respectively). The Wuling Mountains area, where the Wuling Mountains stretch across Chongqing, Hunan, Hubei and Guizhou Provinces, is one of the ten biodiversity hotspot ecoregions considered as conservation priorities in China (TANG et al. 2006). It is characterized by a mountain climate (elevation $200-2570 \mathrm{~m}$ a.s.1.), which is a transition from the sub-tropical to the warm temperate climates. Li River, a major river originated from Wuling Mountains, finally runs into Dongting Lake.

Diatom samples used in this study were collected from two different sites: one from Jinlong power station at
Li River, and the other from Yang's village at Dongting Lake (Table 1). The $\mathrm{pH}$ value and conductivity were measured using an HQ40D Portable Multi Meter (Hach Company, U.S.A) in the field. In Li River, algae were scraped off from stones using a toothbrush, washed into $100 \mathrm{ml}$ sampling bottles, and preserved with $70 \%$ ethanol. In Dongting Lake, epipelic diatoms were separated from the mud using lens tissue, which was removed from the mud surface after one day (MANN et al. 2004). The collected lens tissue was then processed with concentrated nitric and sulphuric acids and rinsed with distilled water five times.

Permanent slides were prepared using Naphrax ${ }^{\circledR}$ mountant and examined using a Leica DM3000 (Germany) light microscopy (LM) equipped with a Leica MC190 HD digital camera. Holotype slides are deposited in the Natural History Museum, London, United Kingdom (BM) while an isotype slide is preserved in the Herbarium of Jishou University, Hunan, People's Republic of China (JIU). Samples were also examined using scanning electron microscopy (SEM). Several drops of the cleaned diatom material were air-dried onto glass coverslips. Coverslips were attached to aluminum stubs using double-sided conductive carbon tape and sputter-coated with platinum (Cressington Sputter Coater 108auto, Ted Pella, Inc.). Samples were examined and imaged using a field emission scanning electron microscopy (FE-SEM) Sigma HD (Carl Zeiss Microscopy, Germany) available at Huaihua University, China.

Terminology related to valve morphology follows Ruck \& Kociolek (2004) and VAN DE ViJVer et al. (2013), and we also illustrate and propose some new terms (Figs 1-2) as follows: Costa-stria bundle (CSB): bundle composed of a few costae and striae all located on the same, somewhat raised, plane level. Over-fibula costa (OFC): a costa placed exactly over one fibula. OFC remains lower than CSB on the valve surface. Mantle sinking against a fibula (MSAF): a mantle sinking which is exactly against an end of a fibula.

\section{Results}

Surirella wulingensis Liu et Ector sp. nov. (Figs 3-20)

\section{Description}

LM (Figs 3-7): Valves linear, with two parallel sides and rounded to cuneate apices (Figs 3-7). Valve dimensions $(n=29$, including 21 valves measured under

Table 1. Two sampling sites for three Surirella species from Li River and Dongting Lake, China, with associated pH, conductivity, and temperature (three replicates).

\begin{tabular}{|c|c|c|c|c|c|c|c|}
\hline Taxon & $\begin{array}{l}\text { Sampling } \\
\text { site }\end{array}$ & Coordinates & $\begin{array}{l}\text { Elevation } \\
\text { (m a.s.I.) }\end{array}$ & pH & $\begin{array}{l}\text { Conductivity } \\
\left(\mu \mathrm{S} . \mathrm{cm}^{-1}\right)\end{array}$ & $\begin{array}{l}\text { Temperature } \\
\left({ }^{\circ} \mathrm{C}\right)\end{array}$ & $\begin{array}{l}\text { Sampling } \\
\text { date }\end{array}$ \\
\hline $\begin{array}{l}\text { S. wulingensis } \\
\text { sp. nov. }\end{array}$ & $\begin{array}{l}\text { Jinlong pow- } \\
\text { er station, Li } \\
\text { River }\end{array}$ & $\begin{array}{l}29^{\circ} 43^{\prime} 7.1^{\prime \prime} \mathrm{N}, \\
109^{\circ} 54^{\prime} 50.9^{\prime \prime} \mathrm{E}\end{array}$ & 398 & $8.5 \pm 0.2$ & $219.3 \pm 1.2$ & $17.9 \pm 0.3$ & $\begin{array}{l}\text { September } \\
30,2015\end{array}$ \\
\hline $\begin{array}{l}\text { S. librile and } S \text {. } \\
\text { tientsinensis }\end{array}$ & $\begin{array}{l}\text { Yang's } \\
\text { village, } \\
\text { Dongting } \\
\text { Lake }\end{array}$ & $\begin{array}{l}28^{\circ} 52^{\prime} 29.5^{\prime \prime N} \\
112^{\circ} 16^{\prime} 52^{\prime \prime} \mathrm{E}\end{array}$ & 57 & $8.3 \pm 0.2$ & $109.3 \pm 0.1$ & $23.5 \pm 0.3$ & $\begin{array}{l}\text { April 23, } \\
2017\end{array}$ \\
\hline
\end{tabular}


Table 2. Morphological comparison among three Surirella species.

\begin{tabular}{|c|c|c|c|c|c|}
\hline & S. librile & S. librile & $\begin{array}{l}\text { S. wulingensis } \\
\text { sp. nov. }\end{array}$ & S. tientsinensis & S. tientsinensis \\
\hline Valve length $(\mu \mathrm{m})$ & $48-190$ & $108-202$ & $99-155$ & $27-67$ & $59-64.5$ \\
\hline Valve width $(\mu \mathrm{m})$ & $11-20$ & $22-26$ & $20-24$ & $9-13$ & $10.2-12$ \\
\hline Valve outline & Panduriform & Panduriform & Linear & Panduriform & Panduriform \\
\hline Valve apex & Cuneate & Gently rounded & $\begin{array}{l}\text { Rounded to cu- } \\
\text { neate }\end{array}$ & Spathulate & Broad capitate \\
\hline Fibulae in $10 \mu \mathrm{m}$ & $9-10$ & $8-10$ & $8-10$ & $6-7$ & 6 \\
\hline Number of portula & 1 & 1 & 1 & 3 & No data \\
\hline Number of undulations & 4 or 6 & No data & 5 & 0 & 0 \\
\hline $\begin{array}{l}\text { Stria type and number in } \\
10 \mu \mathrm{m}\end{array}$ & $\begin{array}{l}\text { Uniseriate except } \\
\text { in the portula, } \\
28-34\end{array}$ & $\begin{array}{l}\text { Uniseriate except } \\
\text { in the portula, } \\
28-36\end{array}$ & $\begin{array}{l}\text { Uniseriate except } \\
\text { in the portula, } \\
31-34\end{array}$ & $\begin{array}{l}\text { Multiseriate, } \\
\text { consisting of } \\
\text { three to four } \\
\text { rows of areolae, } \\
23-26\end{array}$ & No data \\
\hline Areola outer openings & Slit-like & Slit-like & Slit-like & $\begin{array}{l}\text { Rounded and } \\
\text { rimmed }\end{array}$ & No data \\
\hline Areola inside openings & $\begin{array}{l}\text { Rounded and } \\
\text { rimmed }\end{array}$ & $\begin{array}{l}\text { Rounded and } \\
\text { rimmed }\end{array}$ & $\begin{array}{l}\text { Rounded and } \\
\text { rimmed }\end{array}$ & $\begin{array}{l}\text { Rounded and not } \\
\text { rimmed }\end{array}$ & No data \\
\hline $\begin{array}{l}\text { Internal raphe endings at } \\
\text { two apices }\end{array}$ & Both continuous & Both continuous & Both continuous & $\begin{array}{l}\text { One continuous, } \\
\text { the other inter- } \\
\text { rupted }\end{array}$ & No data \\
\hline CSB & $\begin{array}{l}\text { Composed of } \\
3-4 \text { costae and } \\
\text { striae among } \\
\text { these costae }\end{array}$ & $\begin{array}{l}\text { Composed of } \\
3-4 \text { costae and } \\
\text { striae among } \\
\text { these costae }\end{array}$ & $\begin{array}{l}\text { Composed of } \\
2-3 \text { costae and } \\
\text { striae among } \\
\text { these costae }\end{array}$ & $\begin{array}{l}\text { Composed of } \\
3-4 \text { striae and } \\
\text { costae among } \\
\text { these striae }\end{array}$ & No data \\
\hline OFC & $\begin{array}{l}\text { Indicated by } \\
\text { the sinking and } \\
\text { lower position } \\
\text { than the CSB }\end{array}$ & $\begin{array}{l}\text { Indicated by } \\
\text { the sinking and } \\
\text { lower position } \\
\text { than the CSB }\end{array}$ & $\begin{array}{l}\text { Indicated only by } \\
\text { the sinking }\end{array}$ & $\begin{array}{l}\text { Indicated by } \\
\text { the sinking and } \\
\text { lower position } \\
\text { than the CSB }\end{array}$ & No data \\
\hline Pattern of CSBs & $\begin{array}{l}\text { Parallel in the } \\
\text { middle, radiate at } \\
\text { both apices }\end{array}$ & $\begin{array}{l}\text { Parallel in the } \\
\text { middle, radiate at } \\
\text { both apices }\end{array}$ & $\begin{array}{l}\text { Parallel in the } \\
\text { middle, radiate at } \\
\text { both apices }\end{array}$ & $\begin{array}{l}\text { Slightly con- } \\
\text { vergent in the } \\
\text { middle, strongly } \\
\text { radiate at both } \\
\text { apices }\end{array}$ & No data \\
\hline Reference & This study & $\begin{array}{l}\text { RUCK \& KOCI- } \\
\text { OLEK } 2004\end{array}$ & This study & This study & $\begin{array}{l}\text { SkVORTzOV } \\
1927,1938\end{array}$ \\
\hline
\end{tabular}

LM and eight valves under SEM): 71-155 $\mu \mathrm{m}$ long, 19-24 $\mu \mathrm{m}$ wide, fibulae 8-10 (often 9) in $10 \mu \mathrm{m}$. Five distinct undulations present on the valve surface from pole to pole (Figs 3-7).

SEM (Figs 8-20): Valve linear, with two parallel margins and rounded to cuneate apices (Fig. 8). The raphe canal is located directly on the mantle (Figs 8-11), terminal raphe endings simple, slightly curved (Figs 9, 11, arrows). Valve face has intricated, reticulated silica thickenings and white warts (Figs 8-12). The OFCs indicated by longitudinal larger rounded sinkings near the raphe canal, are discernible (Fig. 10, arrows; Fig. 19), but the pattern of CSBs alternating with OFCs is difficult to observe due to their location, almost locating in the same plane (Figs 8-11, 19). The CSB is composed of three costae and two striae among these costae (Figs 19-20). External areolar openings are slit-like (Figs 12, 19). Internally, valve linear with five undulations from pole to pole (Figs 13, 14, labelled U1 to U5). Fibulae are distinct, slim, extending a quarter 
of valve width, ca. 3-4 $\mu \mathrm{m}$ long (Figs 13-18). Raphe continuous at both apices (Figs 15-16, arrows). Striae distinct internally, composed of rounded and rimmed pores (Figs 15-18). Striae uniseriate, except within the portula where they are bi- or triseriate (Figs 17-18), becoming uniseriate out of the portula. The uniseriate striae are $31-34$ in $10 \mu \mathrm{m}$. Areolae $80-100$ in $10 \mu \mathrm{m}$ measured internally. Between two adjacent fibulae, only one portula within which three to four biseriate striae (sometimes with a triseriate stria) occurs.

Holotype: Slide BM 101944, The British Museum of Natural History, London. Fig. 3 represents the holotype. Isotype: Slide G201801, the Herbarium of Jishou University, Hunan, People's Republic of China. Fig. 5 represents the isotype.

Type locality: The Li River course near Jinlong power station $\left(29^{\circ} 43^{\prime} 7.1^{\prime \prime N}, 1^{\circ} 9^{\circ} 54^{\prime} 50.9^{\prime \prime E}\right)$, Wudaoshui Town, Hunan Province, China (Coll. BING LIU, 09/30/2015).

Etymology: Named after Wuling Mountains, where the species was found.

\section{Surirella tientsinensis Skvortzov emend. Liu (Figs 21-44)}

This taxon originally described by SKVORTZOV in 1927 from Tientsin, North China, and only one individual was measured: $64.6 \mu \mathrm{m}$ long, $10.2 \mu \mathrm{m}$ wide (at

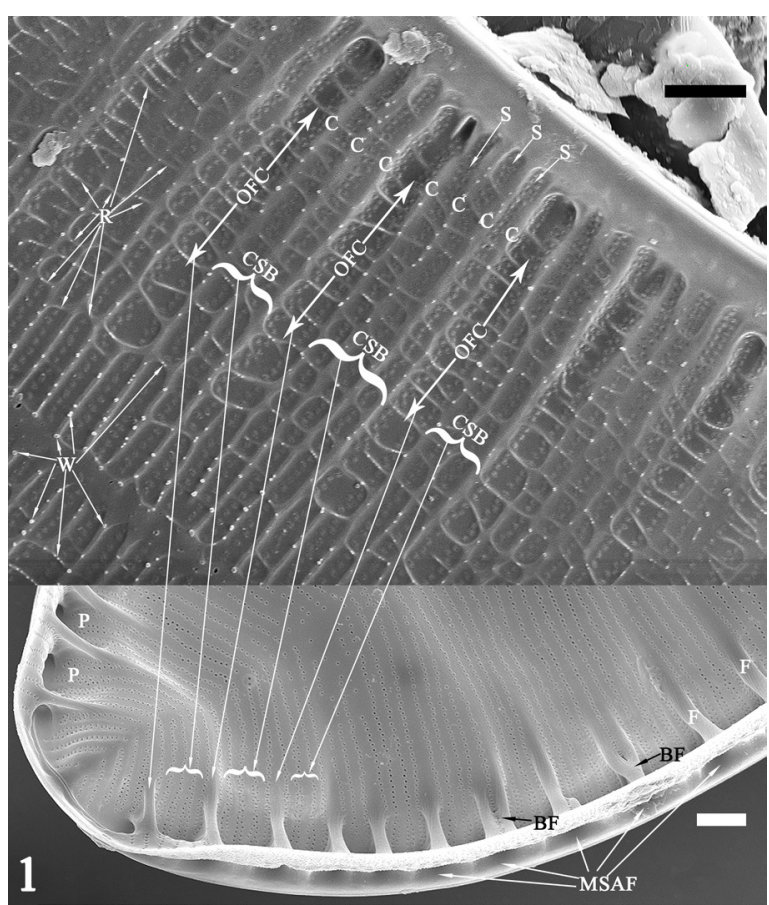

Fig. 1. Valve characters used for describing Surirella taxa (a valve external view and an internal view SEM images from the specimens of Surirella librile collected at Dongting Lake, ). (BF) bifurcate fibula; (C) costa; (CSB) costa-stria bundle; (F) fibula; (MSAF) mantle sinking against a fibula; (OFC) over-fibula costa; $(\mathrm{P})$ portula; $(\mathrm{R})$ reticulate silica thickenings; (S) stria; (W) warts. Note the OFC corresponding to the internal fibula and the CSB corresponding to the internal 3-4 costae and 2-3 striae between two adjacent fibulae. center), $13.6 \mu \mathrm{m}$ (at broadest part), costae 6 in $10 \mu \mathrm{m}$ (Skvortzov 1927: 107, fig. 24). Later, he observed another individual from Hanke Lake, Eastern Siberia, and this individual was measured: $59 \mu \mathrm{m}$ long, $12 \mu \mathrm{m}$ bread (at center), $14 \mu \mathrm{m}$ (at broadest part), costae 6 in $10 \mu \mathrm{m}$ (Skvortzov 1938). Our Dongting Lake Surirella population has the same panduriform valve outline, overlapping also in dimension range, so that it can be safely identified as Surirella tientsinensis. Since to our knowledge, $S$. tientsinensis has never been examined using SEM, we provide hereby an emended description.

\section{Description}

LM (Figs 21-32): Valves panduriform, with a gently constricted middle portion in large valves, more or less linear in smaller ones, apex spathulate (Figs 21-32). Dimensions $(\mathrm{n}=25)$ : valve length $27-67 \mu \mathrm{m}$, width (at centre) 9-13 $\mu \mathrm{m}, 11-15 \mu \mathrm{m}$ at broadest part. Both CSBs and OFCs distinctive, they alternate from pole to pole (Figs 21-32). CSBs slightly convergent at valve middle, becoming strongly radiate at each apex (e.g., Figs 21-25). Median line linear, not reaching each apex (Figs 21-32). Internally, distinct fibulae with the corresponding distribution pattern to the OFCs, almost reach the median line, 6-7 in $10 \mu \mathrm{m}$ (e.g., Figs 28, 32). SEM (Figs 2, 33-44): The above-mentioned attributes

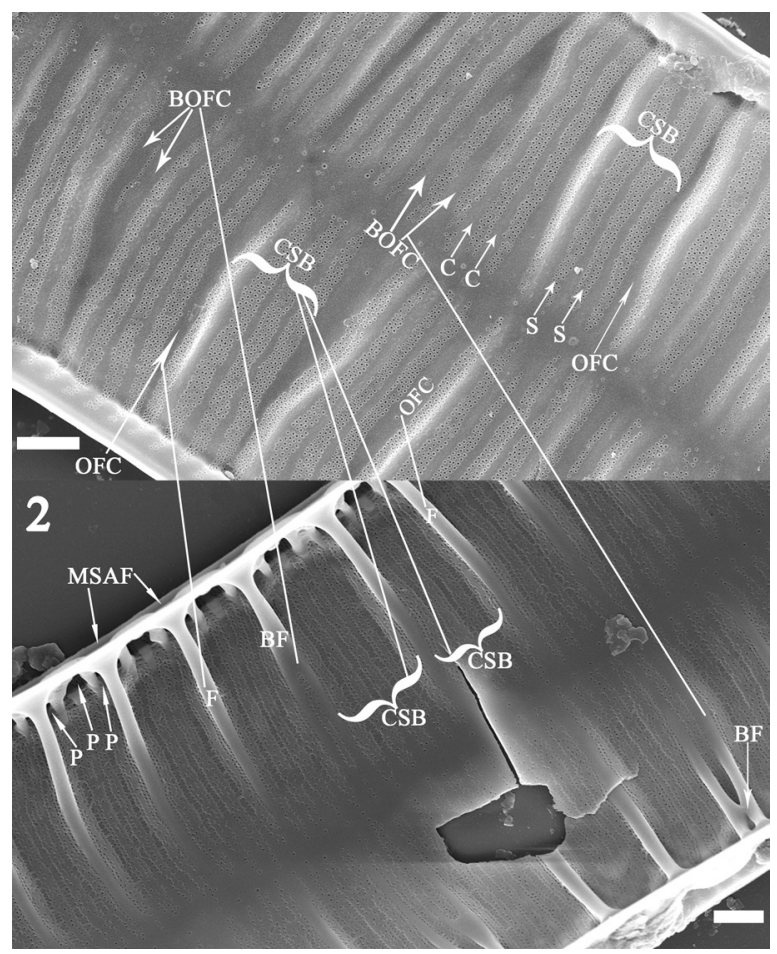

Fig. 2. Valve characters used for describing Surirella taxa (a valve external view and an internal view SEM images from the specimens of Surirella tientsinensis collected at Dongting Lake). (BF) bifurcate fibula; (C) costa; (CSB) costa-stria bundle; (F) fibula; (MSAF) mantle sinking against a fibula; (OFC) over-fibula costa; $(\mathrm{P})$ portula; (S) stria. Note the OFC corresponding to the internal fibula and the CSB corresponding to the internal 3-4 costae and 4-5 multiseriate striae between two adjacent fibulae. Scale bars $1 \mu \mathrm{m}$. 
described with LM observations can be confirmed under SEM (Figs 2, 33-44). Raphe canal located directly on the mantle (Figs 33-35, 38-40), terminal raphe endings simple and straight, not expanded (Figs 34-35). CSBs often composed of three costae and four striae, band-like, slightly elevated off the valve surface (Figs 2, 33-36). OFCs between these bundles, slightly lower (Fig. 36, arrows). At each apex, one CSB appearing pentagonal, the other rounded (Figs 34-35). Indentations present around the circumference of the valve (Figs 34-35, 39). Striae multiseriate, consisting of three to four rows of rimmed, rounded areolae (Fig. 37, two curved arrows). Mantle deep, separated by a slightly raised raphe canal from the valve face; the pattern of CSBs alternating with the OFCs is the same as on the valve face (Figs 39-40). Ornamentation other than the costae and striae absent on valve face, mantle or the raphe canal. Striae 23-26 in $10 \mu \mathrm{m}$ (each row of areolae as a stria).

Internally, fibulae are distinct, slightly convergent at valve centre, becoming strongly radiate towards apices (Fig. 41). Fibulae may be double (Fig. 41, arrows) or bifurcate (Fig. 2, labeled BF). Raphe continuous at one apex but not at the other (Figs 4243). Three portulae are located between two adjacent fibulae: a central broad portula is bordered on each side

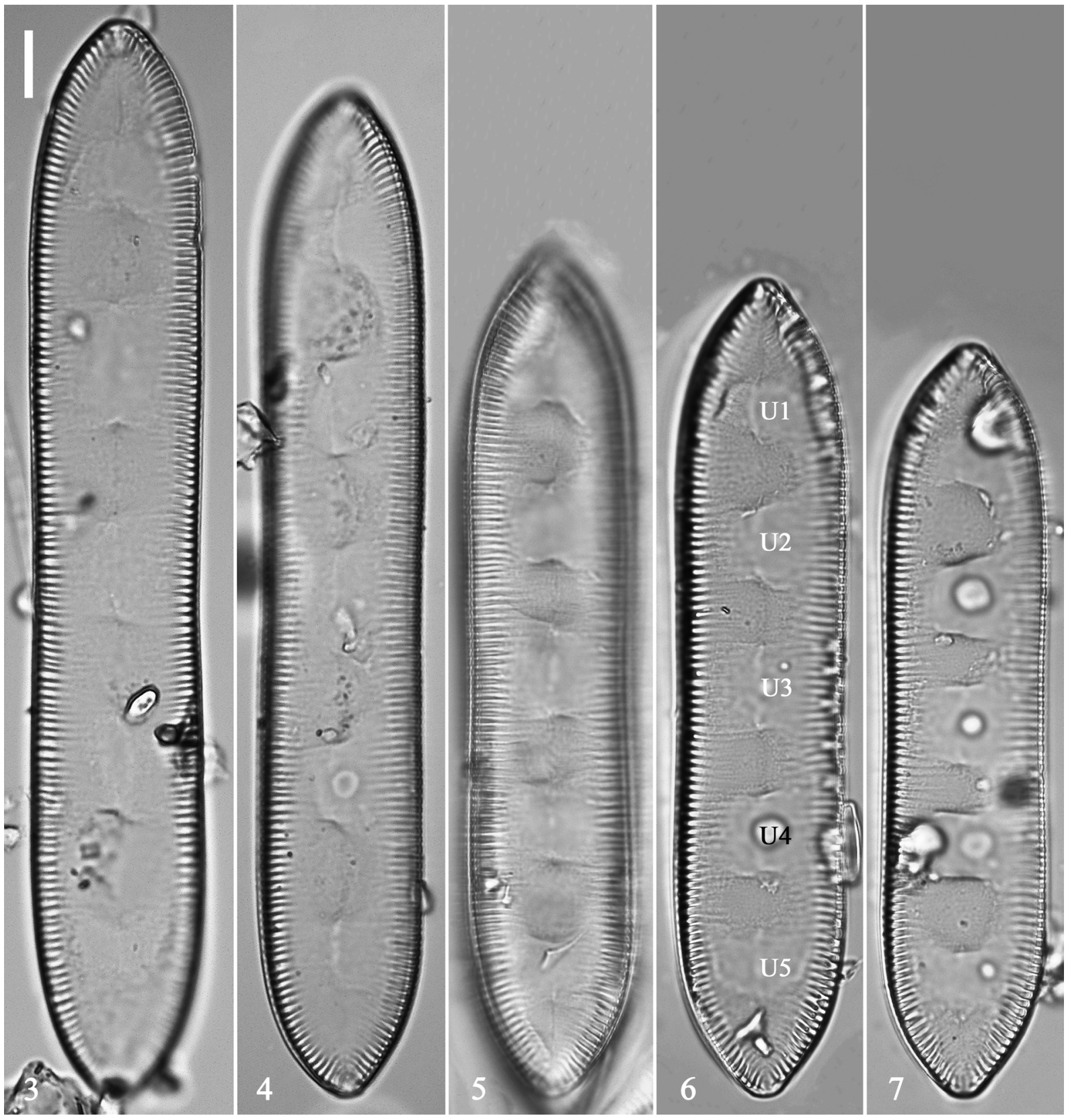

Figs 3-7. Surirella wulingensis sp. nov., LM: (3-7) Five valves showing size diminution, note the parallel valve margins and five distinct undulations from pole to pole (as indicated by labelled U1 to U5 in Fig. 6); (3) Photograph of holotype valve; (5) Photograph of isotype valve. Scale bar $10 \mu \mathrm{m}$ (in 3) for all figures. 

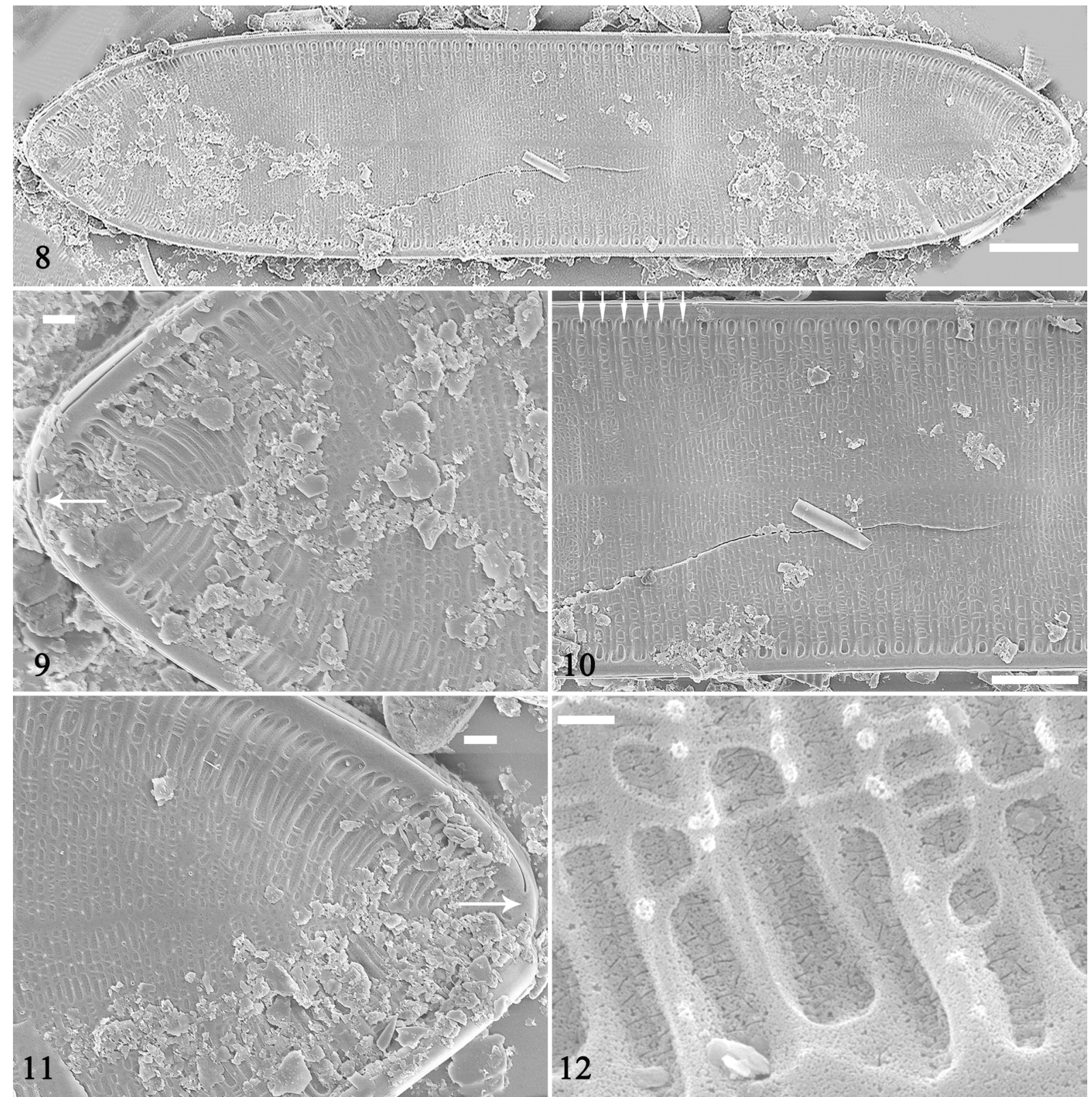

Figs 8-12. Surirella wulingensis sp. nov., SEM, external view: (8) A complete valve showing the parallel valve margins and the discernible undulations from pole to pole; (9) Apex of Fig. 8 showing simple and interrupted raphe endings (arrow); (10) Middle part of Fig. 8 showing a distinct longitudinal row of rounded sinkings (arrows), which indicate locations of the internal fibulae; (11) Another apex of Fig. 8 showing simple and interrupted raphe endings (arrow); (12) Detail of another valve showing the slit-like outer openings of areolae. Scale bars $10 \mu \mathrm{m}$ (8), $5 \mu \mathrm{m}(10), 1 \mu \mathrm{m}(9,11,12)$.

by a smaller one (Fig. 2, labeled P). Striae are distinct internally, composed of round pores without rims (Figs $42-44)$.

\section{Discussion}

Fibulae are important structures for diatoms bearing raphe canal. In Surirella, the fibulae can be spotted externally by their outer structure: the OFC (Figs 1-2). Few authors also noted the corresponding relationship between the OFCs and the fibulae. For example, VAN DE VIJVER et al. (2013, p. 101) described "every fourth or fifth costa is located in the shallow depression, corresponding to the interior fibulae". Many Surirella taxa show this alternate arrangement of between OFCs and CSBs on the valve surface. For example, VAN DE VIJVER et al. (2013, p. 101) used "bundles of three or four costae separated by a deeper indented costa" to describe this alternate arrangement. POTAPOVA \& ENGLISH (2010) stated that "every third or fourth costae on the valve surface is either raised or lowered from the plane of the other costae" describing this feature in S. angusta Kützing.

The most similar taxon to Surirella wulingensis is $S$. regula Ehrenberg. Ehrenberg provided 

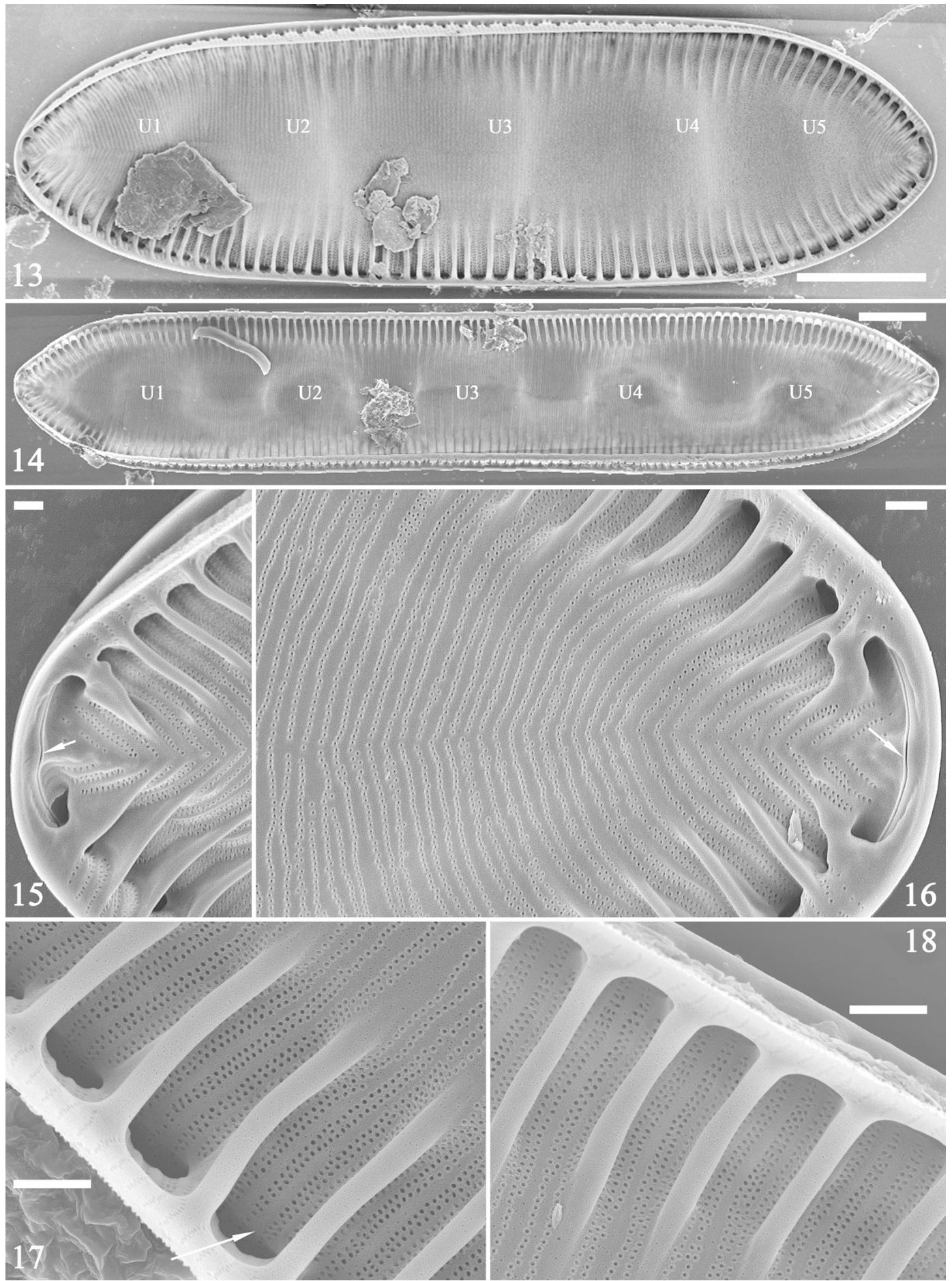

Figs 13-18. Surirella wulingensis sp. nov., SEM, internal view: $(13,14)$ Two complete valves showing parallel valve margins, slim fibulae extending ca. a quarter of valve length, and five discernible undulations from pole to pole (labelled U1 to U5); $(15,16)$ Two apices showing the continuous raphe (arrows); $(17,18)$ Two details of valve middle part showing portulae and often four biseriate striae between adjacent two fibulae, occasionally five (Fig. 17, arrow), note the areolae within the portulae not rimmed. Scale bars $10 \mu \mathrm{m}(13,14), 1 \mu \mathrm{m}(15-18)$.

two drawing line figures: fig. 3a in valve view show six undulations on the surface from pole to pole, fig. $3 \mathrm{~b}$ in girdle view also show these undulations. Ralfs (in Pritchard 1861) transferred S. regula into Cymatopleura. Although Ralfs did not provide any illustrations, he gave this description: "Lateral view linear, with cuneate ends and six transverse bars".
GRUNOw (1862) transferred S. regula to Cymatopleura solea as Cymatopleura solea var. regula but did not give any description or illustration. HUSTEDT (1930, p. 425 , fig. 823b) did not give any description but provided a drawing line figure for Cymatopleura solea var. regula. This drawing line figure presented a specimen in valve view showing also six undulations from pole 


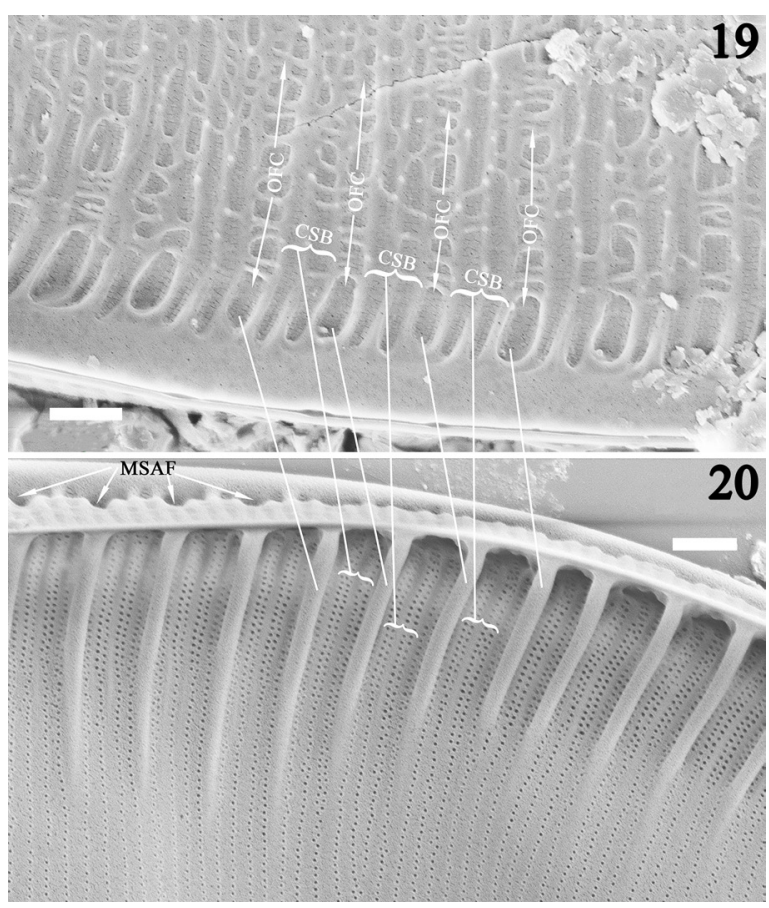

Figs 19, 20. Surirella wulingensis sp. nov., SEM: (19) Detail of valve external surface; (20) Detail of valve internal surface; $(19,20)$ Two details showing the correspondence between the external valve elements (CSBs and OFCs) and the internal valve elements (costae, striae, and fibulae), note the pattern of the CSBs alternating with OFCs is not as conspicuous as in S. librile (cf. Fig. 1). Note each CSB corresponding to the internal three costae and two striae between two adjacent fibulae. Scale bars $1 \mu \mathrm{m}$.
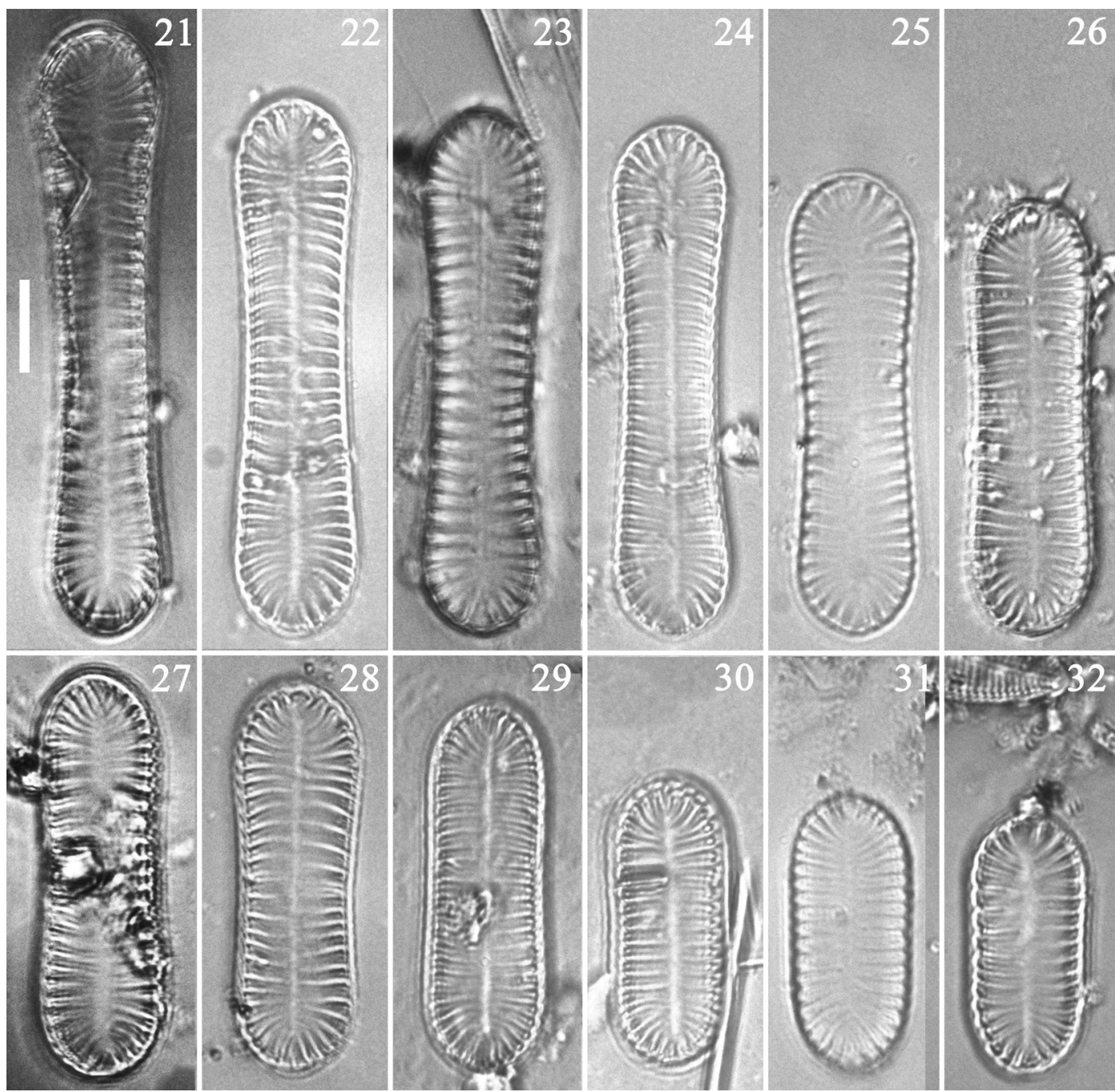

Figs 21-32. Surirella tientsinensis, LM: (21-32) Twelve valves showing size diminution, note the panduriform valve outline in large specimens (e.g. Figs 21-25) gradually becoming nearly linear in small specimens (e.g. Figs 29-32). Scale bars $10 \mu \mathrm{m}$ (in 21) for all figures. 

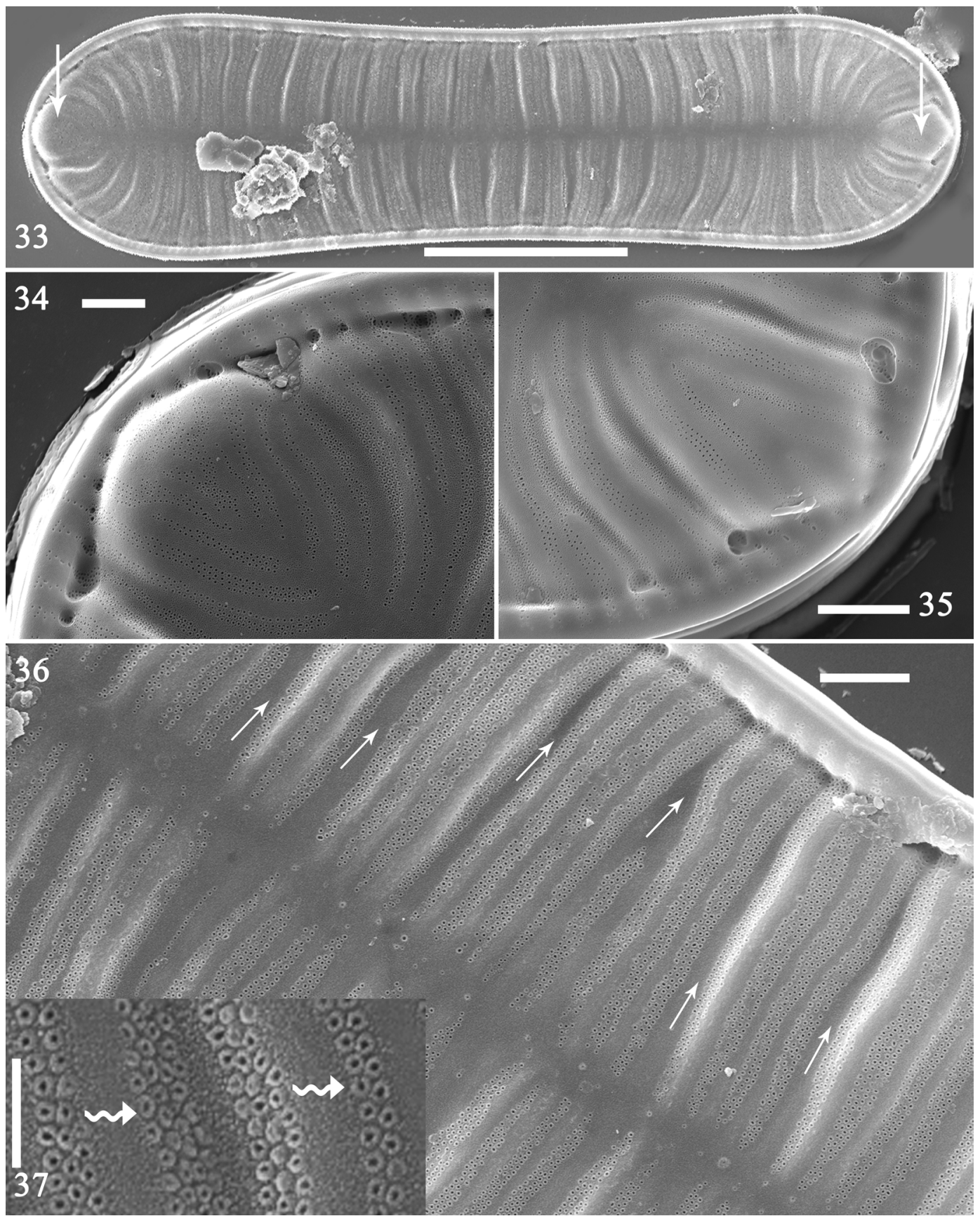

Figs 33-37. Surirella tientsinensis, SEM, external view: (33) A complete valve showing the panduriform valve outline and the pattern of CSBs alternating with OFCs, note a distal pentagonal CSB and another rounded one (two arrows); $(34,35)$ Two apices showing the straight terminal raphe endings, indentations near the end of striae, and two distal CSBs; (36) Middle part detail of Fig. 33 showing the multiseriate striae, CSBs (cf. Fig. 2), and OFCs (arrows); (37) Detail of the rimmed outer openings of areolae (curved arrows). Scale bars $10 \mu \mathrm{m}(33), 1 \mu \mathrm{m}(34-37)$.

to pole. From these authors' reports, S. regula can be confirmed bearing six undulations on the valve surface from pole to pole. In contrast, Surirella wulingensis possesses five distinct undulations on the valve surface from pole to pole, as confirmed by both LM (Figs 3-7) and SEM images (Figs 8, 13, 14). Thus, Surirella wulingensis can be confirmed as a different species from S. regula.

Another similar taxon is Cymatopleura comperei COCQUYT \& R. JAHN (2014, p. 419). Cymatopleura comperei has five weak undulations, but it has slightly constricted valve middle margins; more importantly, its valve surface is almost smooth without delicate reticulate thickenings and only scattered silica granules (warts) present. Thus, Surirella wulingensis and $C$. comperei are not conspecific.

\section{ACKNOWLEDGEMENTS}

We are grateful to Professor J. Patrick Kociolek for his assistance, to Dr. Xin Yang of Huaihua University for help with SEM operation and photography. This research was supported by the National Natural Science Foundation of China (No. 31760051) and the 


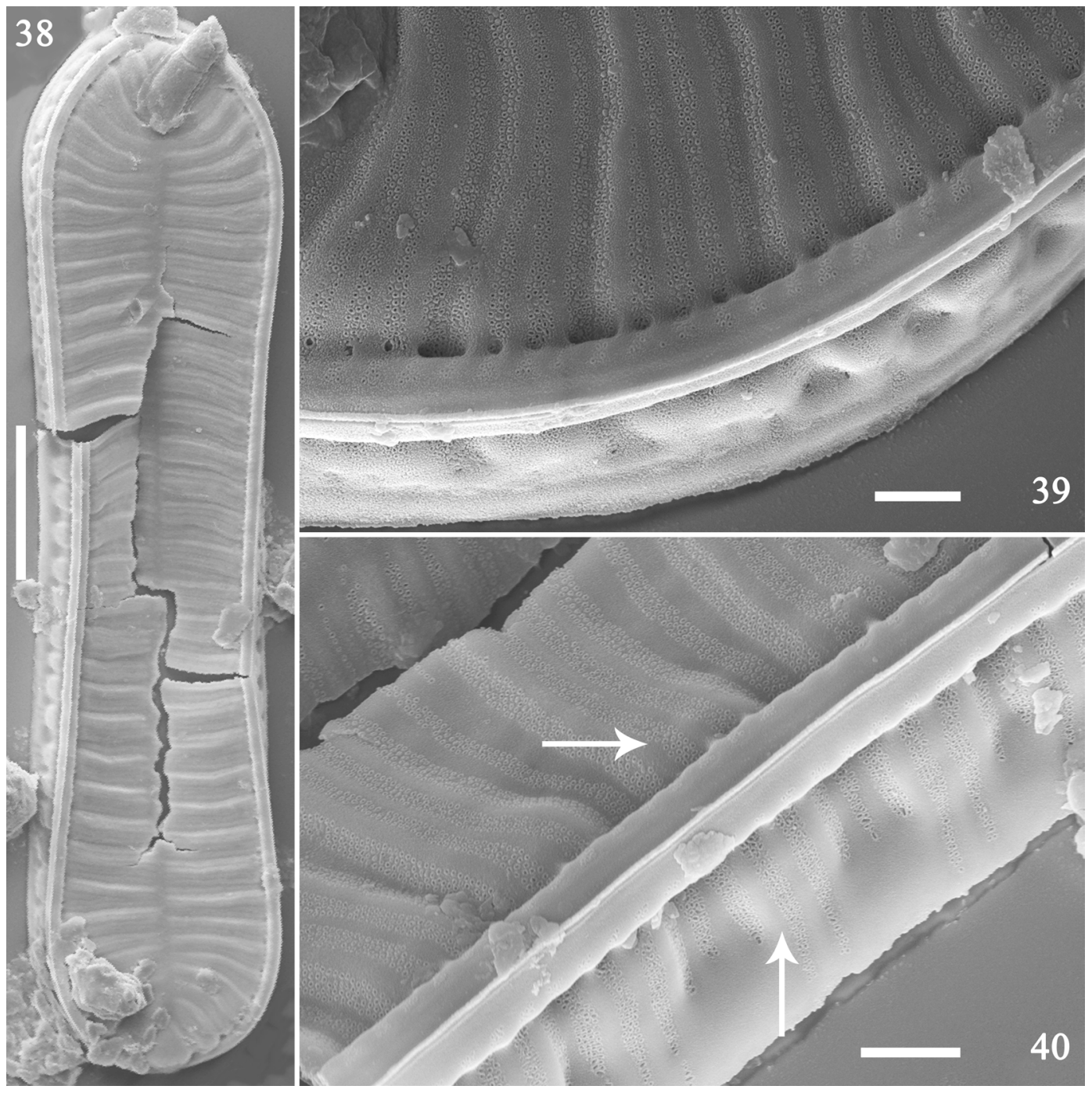

Figs 38-40. Surirella tientsinensis, SEM, external view: (38) A broken valve, note the deep mantle; (39) Detail of Fig. 38 showing the canal raphe system and the deep mantle; (40) Another detail of Fig. 38 showing the striae interrupted by the keel and the same pattern of CSBs alternating with OFCs on the mantle (two arrows). Scale bars $10 \mu \mathrm{m}(38), 1 \mu \mathrm{m}(39,40)$.

Natural Science Foundation of Hunan (No. 2018JJ2311).

\section{REFERENCES}

CocQuYT, C. \& JAHN, R. (2014): A re-investigation of Otto Müller's Cymatopleura taxa (Bacillariophyta) from East Africa. - Plant Ecology and Evolution 147: 412-425. https://doi.org/10.5091/plecevo.2014.992

EHRENBERG, C.G. (1845): Vorläufige zweite Mettheilung über die weitere Erkenntnifs der Beziehungen des kleinsten organischen Lebens zu den vulkanischen Massen der Erde. - Bericht über die zur Bekanntmachung geeigneten Verhandlungen der Königlich-Preussischen Akademie der Wissenschaften zu Berlin 1845: 133-157.

FAN, Y.W. \& Hu, Z.Y. (2004): Studied on Aulonoraphidinales from Xingkaihu Lake in Heilongjlang Province. - Acta Hydrobiologica Sinica 28: 421-425 (in Chinese)

Grunow, A. (1862): Die österreichischen Diatomaceen nebst Anschluss einiger neuen Arten von andern
Lokalitäten und einer kritischen Uebersicht der bisher bekannten Gattungen und Arten. Erste Folge. Epithemieae, Meridioneae, Diatomeae, Entopyleae, Surirelleae, Amphipleureae. - Verhandlungen der kaiserlich-königlichen zoologisch-botanischen Gesellschaft in Wien 12: 315-472, pls III (6)-VIII (11).

Haraguchi, K. (1997): Diatoms from Lake Aoki, Nagano Prefecture, Central Japan. - Diatom 13: 215-231 (in Japanese). https://doi.org/10.11464/ diatom1985.13.0 215

Haraguchi, K. (2000): Diatoms from Sugao-numa (Sugao Swamp) in Ibaragi Prefecture, Central Japan. - Diatom 16: 63-74 (in Japanese). https://doi. org/10.11464/diatom1985.16.0_63

HustedT, F. (1930): Bacillariophyta (Diatomeae). In: Pascher, A. (ed.): Die Süsswasser-Flora Mitteleuropas, Heft 10. - 466 pp., Gustav Fischer Verlag, Jena. Zweite Auflage.

JAHN, R.; Kusber, W.-H. \& COCQUYT, C. (2017): Differentiating Iconella from Surirella (Bacillariophyceae): typifying four Ehrenberg names 


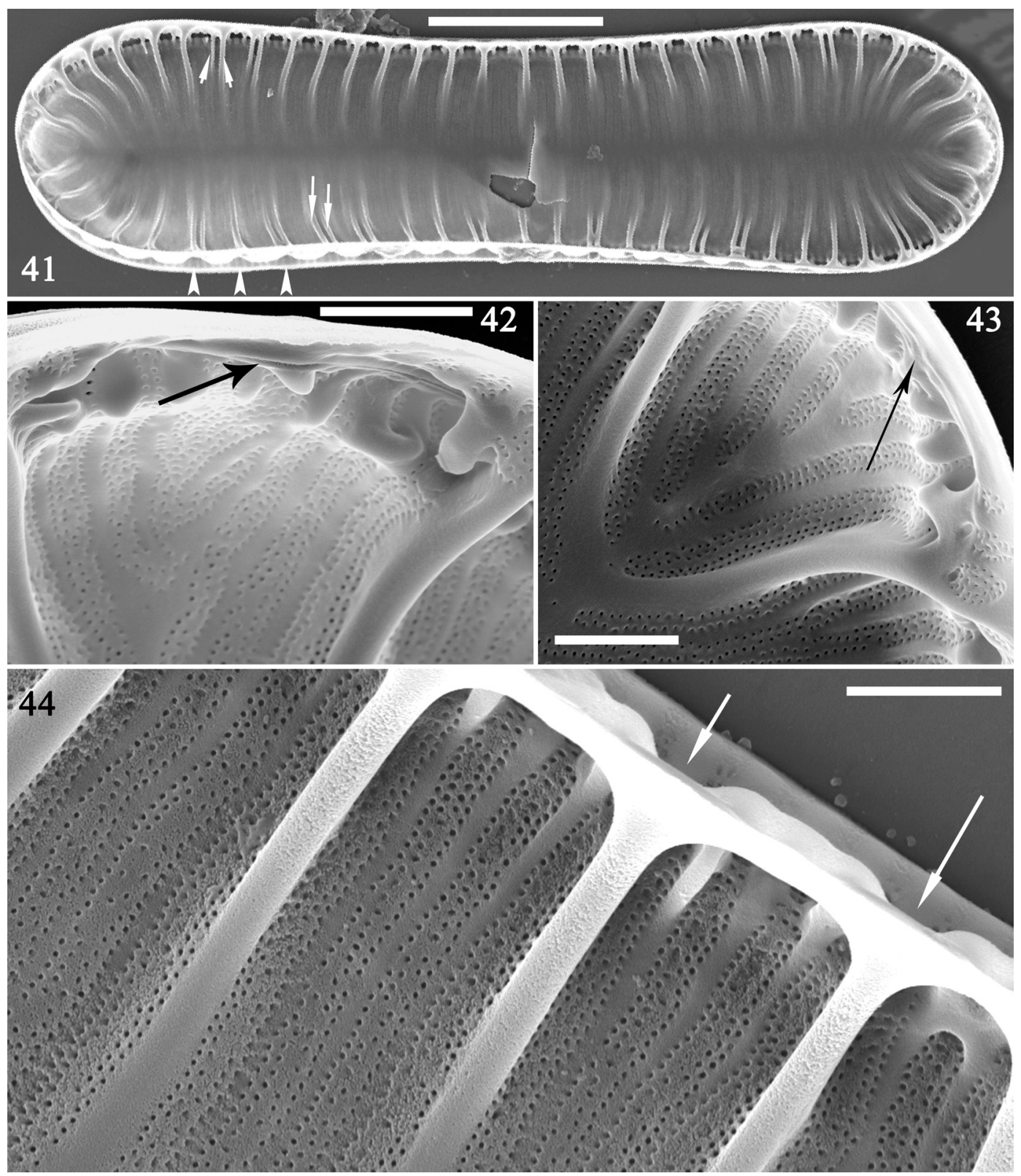

Figs 41-44. Surirella tientsinensis, SEM, internal view: (41) A complete valve showing the valve panduriform outline, the distribution of fibulae from pole to pole, double-form fibulae (arrows), and mantle sinks against the fibulae (arrowheads); (42) Apex detail showing the continuous raphe (arrow); (43) Another apex detail showing the interrupted raphe endings (arrow); (44) Middle part detail showing three portulae and four multiseriate striae between two adjacent fibulae and mantle sinkings against the fibulae (two arrows). Scale bars $10 \mu \mathrm{m}(41), 1 \mu \mathrm{m}(42-44)$.

and a preliminary checklist of the African taxa. PhytoKeys 82: 73-112. https://doi.org/10.3897/ phytokeys.82.13542

Kharitonov, V.G. (2010): Diatoms (Bacillariophyceae) in sediments of three mountain oligotrophic lakes of the Amguema River basin (Chukotka). - Contemporary Problems of Ecology 3: 435-448. https://doi. org/10.1134/S1995425510040077

Krammer, K. \& Lange-Bertalot, H. (1987): Morphology and taxonomy of Surirella ovalis and related taxa. - Diatom Research 2: 77-95. https://doi. org/10.1080/0269249X.1987.9704986

LiU, B.; Blanco, S.; Long, H.; XU, J. \& Jiang, X. (2016): Achnanthidium sinense sp. nov. (Bacillariophyta) from the Wuling Mountains Area, China. - Phytotaxa
284: 194-202. https://dx.doi.org/10.11646/ phytotaxa.284.3.4

LiU, B.; Williams, D.M. \& Tan, L. (2017): Three new species of Ulnaria (Bacillariophyta) from the Wuling Mountains Area, China. - Phytotaxa 306: 241-258. https://doi.org/10.11646/phytotaxa.306.4.1

LiU, B.; Blanco S. \& LAN Q.Y. (2018a): Ultrastructure of Delicata sinensis Krammer et Metzeltin and D. williamsii sp. nov. (Bacillariophyta) from China. - Fottea 18: 30-36. https://doi.org/10.5507/fot.2017.009

Liu, B.; Williams, D.M. \& Ector, L. (2018b): Entomoneis triundulata sp. nov. (Bacillariophyta), a new freshwater diatom species from Dongting Lake, China. - Cryptogamie, Algologie 39: 239-253. https://doi. org/10.7872/crya/v39.iss2.2018.239 
Mann, D.G. (1987): Sexual reproduction in Cymatopleura. - Diatom Research 2: 97-112. https://doi. org/10.1080/0269249X.1987.9704987

Mann, D.G.; McDonald, S.M.; Bayer, M.M.; Droop, S.J.M.; Chepurnov, V.A.; LoKe, R.E.; Ciobanu, A. \& DU Buf, J.M.H. (2004): The Sellaphora pupula species complex (Bacillariophyceae): morphometric analysis, ultrastructure and mating data provide evidence for five new species. - Phycologia 43: 459-482. https://doi.org/10.2216/i0031-8884-43-4-459.1

OBRezkova, M.S. (2009): Diatom flora of surface sediments of the Amur River Estuary and adjacent areas of the Sea of Japan and the Sea of Okhotsk. - Russian Journal of Marine Biology 35: 138-150. https://doi. org/10.1134/S1063074009020059

Peragallo, H. \& Peragallo, M. (1897-1908): Diatomées marines de France et des districts maritimes voisins. - Micrographe-Éditeur, Grez-sur-Loing (S.-et M.), $491 \& 48$ p., 137 pls.

Potapova, M. \& English, J. (2010): Surirella angusta. In Diatoms of North America. Retrieved October 08, 2018, from https://diatoms.org/species/ surirella angusta

Pritchard, A. (1861): A history of infusoria, living and fossil: arranged according to Die infusionsthierchen of C.G. Ehrenberg; containing colored engravings, illustrative of all the genera, and descriptions of all the species in that work, with several new ones; to which is appended an account of those recently discovered in the chalk formations. xii. Edition IV, revised and enlarged by J.T. Arlidge, W. Archer, J. Ralfs, W.C. Williamson and the author. - xiii + 968 pp., 40 pls, London, Whittaker and Co. https://doi.org/10.5962/ bhl.title. 7440

Ruck, E.C. \& Kociolek, J.P. (2004): Preliminary phylogeny of the family Surirellaceae (Bacillariophyta). - Bibliotheca Diatomologica 50: $1-236$.

Ruck, E.C.; Nakov, T.; Alverson, A.J. \& Theriot, E.C. (2016): Phylogeny, ecology, morphological evolution, and reclassification of the diatom orders Surirellales and Rhopalodiales. - Molecular Phylogenetics and Evolution 103: 155-171. http:// dx.doi.org/10.1016/j.ympev.2016.07.023

Skvortzow, B.W. (1927): Diatoms from Tientsin, North China. - Journal of Botany, British and Foreign 65: 102-109.

Skvortzow, B.W. (1938): Diatoms from Argun River, Hsing-An-Pei Province, Manchoukuo. - Philippine Journal of Science 66: 43-74.

TANG, Z.Y.; WANG, Z.H.; ZhENG, C.Y. \& FANG, J.Y. (2006): Biodiversity in China's mountains. - Frontiers in Ecology and the Environment 4: 347-352. https:// doi.org/10.1890/1540-9295(2006)004[0347:BICM] 2.0. $\mathrm{CO} ; 2$

VAN De ViJver, B.; Cocquyt, C.; De HaAn, M.; Kopalová, K. \& Zidarova, R. (2013): The genus Surirella (Bacillariophyta) in the sub-Antarctic and maritime Antarctic region. - Diatom Research 28: 93-108. https://doi.org/10.1080/0269249X.2012.739975

You, Q.; KocioleK, J.P.; CaI, M.; YU, P. \& WANG, Q. (2017): Two new Cymatopleura taxa (Bacillariophyta) from Xinjiang, China with slightly twisted frustules. - Fottea 17: 293-302. https://doi.org/10.5507/ fot.2017.014

(C) Czech Phycological Society (2019)

Received November 13, 2018

Accepted May 5, 2019 